\title{
A Comparison of Energy Consumption in Hydrothermal Liquefaction and Pyrolysis of Microalgae
}

\author{
Bo Zhang $^{1 *}$, Jinsheng $\mathrm{Wu}^{1}$, Zhao Deng ${ }^{1}$, Changyan Yang ${ }^{1,2^{*}}$, Chang Cui ${ }^{1}$, Yigang Ding ${ }^{1}$ \\ 1: Key Laboratory for Green Chemical Process of Ministry of Education, Hubei Key Laboratory of Novel \\ Chemical Reactor and Green Chemical Technology, School of Chemical Engineering and Pharmacy, \\ Wuhan Institute of Technology, Hubei, China \\ 2: Hubei Key Laboratory for Processing and Application of Catalytic Materials, Huanggang Normal \\ University, Hubei, China
}

Received December 2, 2016; Accepted December 25, 2016; Published January 1, 2017

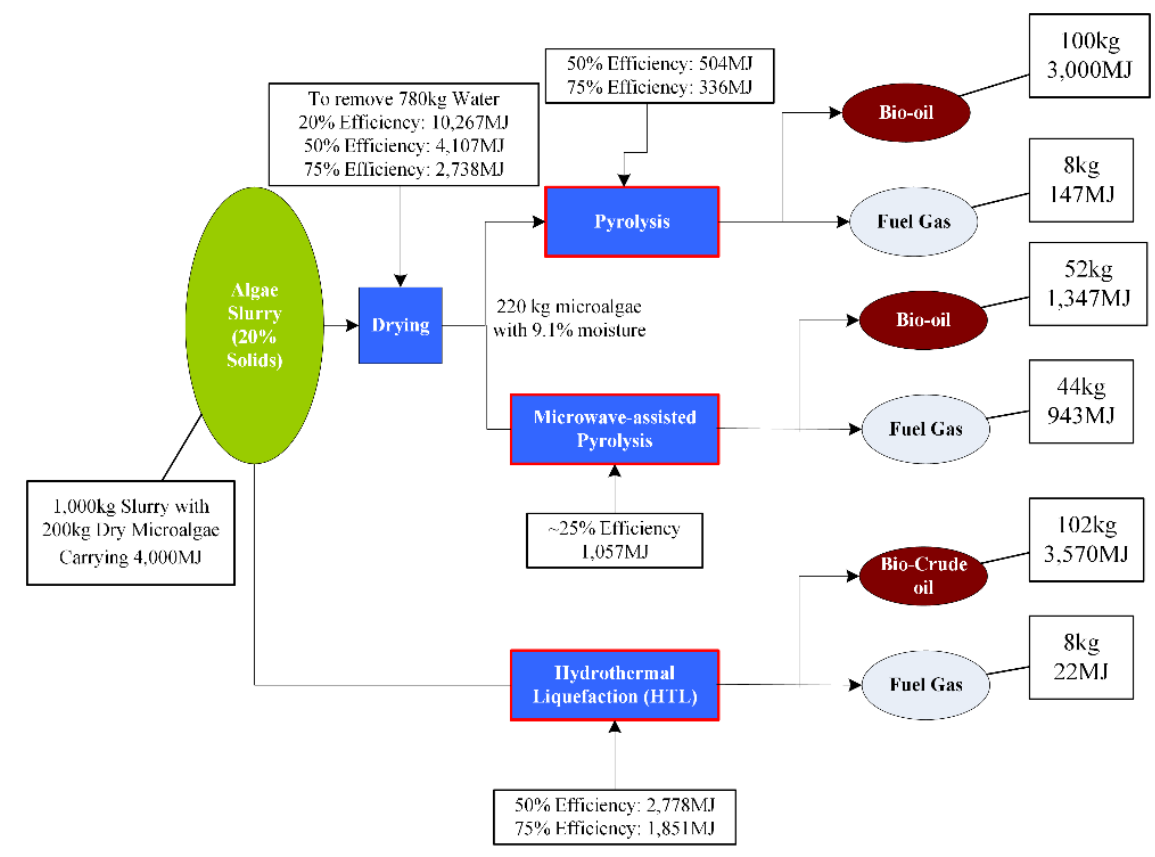

The energy requirements for converting one tonne $(1,000 \mathrm{~kg})$ of Chlorella slurry of $20 \mathrm{wt} \%$ solids via fast pyrolysis, microwave-assisted pyrolysis (MAP), and hydrothermal liquefaction (HTL) were compared. Drying microalgae prior to pyrolysis by using a spray drying process with a $50 \%$ energy efficiency required an energy input of 4,107 MJ, which is higher than the energy content $(4,000 \mathrm{MJ})$ of raw microalgae. The energy inputs to conduct fast pyrolysis, MAP, and HTL reactions were $504 \mathrm{MJ}(50 \%$ efficient), 1,057 MJ ( 25\% efficient), and 2,776 MJ (50\% efficient), respectively. The overall energy requirement of fast pyrolysis is theoretically about 1.6 times more than that of HTL. The energy recovery ratios for fast pyrolysis, MAP, and HTL of microalgae were $78.7 \%, 57.2 \%$, and $89.8 \%$, respectively. From the energy balance point of view, hydrothermal liquefaction is superior, and it achieved a higher energy recovery with a less energy cost. To improve the pyrolysis process, developing drying devices powered by renewable energies, optimizing the pyrolysis process (specifically microwave-assisted), and improving the energy efficiency of equipment are options. 
Keywords: Microalgae; Energy Consumption; Pyrolysis; Hydrothermal Liquefaction (HTL); Microwaveassisted pyrolysis; Thermal Drying

\section{Introduction}

Thermochemical conversion of microalgae can be divided into pyrolysis of dry algae and hydrothermal liquefaction (HTL) of algal slurries [1]. Usually, the microalgal culture has a very dilute concentration of $0.1-1 \%$ dry solids. Currently, the proposed harvesting process is using a series of mechanical unit operations to dewater the microalgae media to a level of $\sim 20 \%$ dry solids, which is considered as a less energy intensive processing option than completely drying microalgae for pyrolysis purpose. Drying is one of most dominant costs for algae harvest and may account for $30 \%$ of the total product costs, and the power consumption was equivalent to $15.8 \%$ of the energy of the recovered hydrocarbon [2]. Because of this energy consumption barrier, pyrolysis is considered as a kind of hopeless technologies for microalgae and only limited to laboratory investigations [3]. Meanwhile, researchers also recognized the advantages of the pyrolysis of microalgae (such as higher quality of pyrolytic bio-oil than that of cellulosic biomass) [4] and the merits of pyrolysis technology (such as lower capital cost than HTL) $[5,6]$.

This paper provides a simple comparison between the energy consumptions in pyrolysis of microalgae and hydrothermal liquefaction of microalgae. The purpose is not to provide a complete evaluation to these conversion technologies, but to give an idea how the energy consumption impacted the conversion processes of microalgae, and what would be the possible solutions.

\section{Methodology}

\section{Microalgae}

The composition analysis and properties of Chlorella sp. are summarized in Table 1. An engineered Chlorella sp. was assumed to be grown autotrophically, and had following components: $25 \%$ fatty acids, $50 \%$ protein, $15 \%$ polysaccharide, and $10 \%$ ash. For calculation, one tonne $(1,000 \mathrm{~kg})$ of Chlorella slurry at $20^{\circ} \mathrm{C}$ with $20 \mathrm{wt} \%$ solids and $80 \mathrm{wt} \%$ water (i.e. $200 \mathrm{~kg}$ dry algal cells and $800 \mathrm{~kg}$ water) was selected as the baseline. Cell concentration of $20 \mathrm{wt} \%$ has been used in multiple technical reports published by US national laboratories $[7,8]$. This kind of algal slurries can be obtained via a series of dewatering unit operations such as settling, dissolved air flotation, and centrifugation. The energy content of microalgae is $\sim 20 \mathrm{MJ} / \mathrm{kg}$, so this microalgal slurry carried 4,000 MJ.

Table 1. Composition analysis and properties of C. vulgaris [9-12]

\begin{tabular}{|c|c|c|c|}
\hline Protein (wt\%) & $34-58.1$ & Specific heat $(\mathrm{kJ} / \mathrm{kg} \cdot \mathrm{K})^{*}$ & 1.57 \\
\hline Polysaccharide (wt\%) & $9.42-15.5$ & $\begin{array}{l}\text { Molecular weight } \\
\text { (g/mol)* }\end{array}$ & 360 \\
\hline Lipid (wt\%) & $1.04-15.6$ & HHV (MJ/kg) & $19.3-21.2$ \\
\hline $\mathrm{C}(\mathrm{wt} \%)$ & $44.5-50.2$ & Volatile matter $(\mathrm{wt} \%)$ & $51.8-75.2$ \\
\hline H (wt\%) & $6.2-7.2$ & Fixed carbon (wt\%) & $9-32.1$ \\
\hline $\mathbf{N}(w t \%)$ & $6.4-10.9$ & $\operatorname{Ash}(w t \%)$ & $9.6-11.4$ \\
\hline$O(w t \%)$ & $24.6-40.7$ & & \\
\hline
\end{tabular}

* [13] 
Fast pyrolysis and microwave-assisted pyrolysis processes

Prior to pyrolysis, the microalgal slurry $(1,000 \mathrm{~kg})$ was dried with a spray dryer to $220 \mathrm{~kg}$ with a $9.1 \%$ moisture. Spray drying could generate Chlorella powders consisted of globular particles with a diameter of approximately $50-80 \mu \mathrm{m}$ (i.e. $0.05-0.08 \mathrm{~mm}$, approximately 270- 200 mesh) [14], which is fine enough for fast pyrolysis. Fast pyrolysis of microalgal powders were conducted in a fluidized bed reactor at $500^{\circ} \mathrm{C}$ with a heating rate of $600{ }^{\circ} \mathrm{C} / \mathrm{s}$. Pyrolytic product yields were assumed to be following: the bio-oil yield was $50 \mathrm{wt} \%$, the yield of water solubles was $15 \mathrm{wt} \%$, gaseous products counted for $4 \mathrm{wt} \%$, and the biochar yield was $28 \mathrm{wt} \%$. The gaseous products consisted of $22.2 \mathrm{vol} \% \mathrm{H}_{2}, 34.9$ vol $\% \mathrm{CH}_{4}, 38.6$ vol $\% \mathrm{CO}_{2}$, and 4.3 vol $\% \mathrm{C}_{2} \mathrm{H}_{6}$ [11].

For microwave-assisted pyrolysis, microalgae could be air-dried by using solar dryers (Figure 1), because microwave pyrolysis doesn't require the finely ground feed [15, 16]. Microwave-assisted pyrolysis was assumed to be conducted in a pilot scale system, which could process large chunks of dry microalgae [17]. Pyrolytic product yields were assumed to be following: the bio-oil yield is $26 \mathrm{wt} \%$, the yield of water solubles was 24 $\mathrm{wt} \%$, gaseous products counted for $22 \mathrm{wt} \%$, and the biochar yield is $28 \mathrm{wt} \%$ [10].
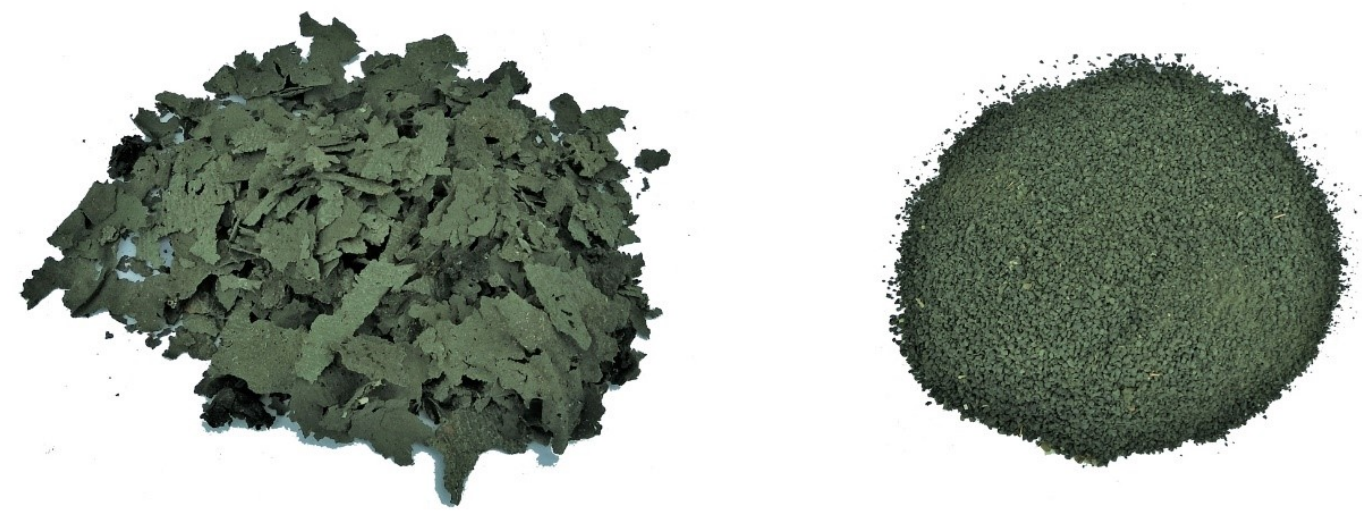

Figure 1. Naturally dried microalgae $(A)$ and ground microalgae $(B)$

\section{Hydrothermal liquefaction (HTL)}

The microalgal slurry of $20 \mathrm{wt} \%$ solids was pumped to the HTL reactor, and hydrothermally treated in subcritical water at $2,500-3,000$ psia and $350^{\circ} \mathrm{C}$. The HTL process yielded $4 \mathrm{wt} \%$ gases, $51 \mathrm{wt} \%$ bio-crude oil, and $43 \mathrm{wt} \%$ aqueous organics and ash [5]. The non-condensable gases had following composition: $42 \mathrm{vol} \% \mathrm{CO}_{2}, 50 \mathrm{vol} \% \mathrm{NH}_{3}$, $7 \mathrm{vol} \% \mathrm{CH}_{4}$, and $1 \mathrm{vol} \%$ ethane [18]. The non-condensable gases were mixed with natural gas and sent to a steam boiler for power generation. The predominately organic liquid phase is sent to catalytic upgrading, and the predominately aqueous phase is sent to wastewater cleanup for carbon recovery. Solids that can be removed by filtration might be recycled back to the algae ponds as nutrients [14]. The conditions and product yields for pyrolysis and HTL processes used in this study are summarized in Table 2. 
Table 2. Conditions and product yields of pyrolysis and hydrothermal liquefaction of microalgae

\begin{tabular}{|l|l|l|l|}
\hline & Fast Pyrolysis $\left(500^{\circ} \mathrm{C}\right)$ & $\begin{array}{l}\text { Microwave-assisted } \\
\text { Pyrolysis }\end{array}$ & HTL $\left(350^{\circ} \mathrm{C}\right)$ \\
\hline Reaction temperature & $500^{\circ} \mathrm{C}$ & - & $350^{\circ} \mathrm{C}$ \\
\hline Pressure & Atmospheric pressure & Atmospheric pressure & $2500-3000 \mathrm{psia}$ \\
\hline Bio-oil $(\mathrm{wt} \%)$ & 50 & 26 & 51 \\
\hline Water $(\mathrm{wt} \%)$ & 15 & 24 & - \\
\hline Biochar yield $(\mathrm{wt} \%)$ & 28 & 28 & - \\
\hline Gaseous products $(\mathrm{wt} \%)$ & 4 & 22 & 4 \\
\hline
\end{tabular}

\section{Calculation}

Specific heat of microalgae

According to a scientific report that studied the thermo-chemical properties of six species of microalgae, the specific heat $\left(\mathrm{c}_{\mathrm{p}}\right)$ of microalgae was determined as $1.2-2$ $\mathrm{kJ} / \mathrm{kg} \cdot \mathrm{K}$ [13]. Meanwhile, to calculate the specific heat of microalga from its composition, following assumptions were applied: ash is $\mathrm{SiO}_{2}$ with a specific heat of $733 \mathrm{~J} / \mathrm{kg} \cdot \mathrm{K}$ or 0.175 $\mathrm{cal} / \mathrm{g} \cdot{ }^{\circ} \mathrm{C}$, the specific heat of polysaccharides is same as that of glucose $\left(0.3 \mathrm{cal} / \mathrm{g} \cdot{ }^{\circ} \mathrm{C}\right)$, the specific heat of fatty acids is same as that of stearic acid $\left(0.55 \mathrm{cal} / \mathrm{g} \cdot{ }^{\circ} \mathrm{C}\right)$, and the specific heat of protein is same as that of quinolone $\left(0.352 \mathrm{cal} / \mathrm{g} \cdot{ }^{\circ} \mathrm{C}\right)$. Thus, the specific heat of Chlorella sp. was determined via Eqn. 1 as $0.376 \mathrm{cal} / \mathrm{g} \cdot{ }^{\circ} \mathrm{C}$ or $1.57 \mathrm{~kJ} / \mathrm{kg} \cdot \mathrm{K}$.

Specific heat of microalga $\left(c_{\mathrm{p}}\right.$, microalgae)

$=10 \% \times 0.175+25 \% \times 0.55+50 \% \times 0.352+15 \% \times 0.3=0.376 \mathrm{cal} / \mathrm{g} \cdot{ }^{\circ} \mathrm{C}$

Eqn. 1

\section{Energy for thermal drying of microalgal slurry}

The feedstock for pyrolysis is typically quoted at $<10 \mathrm{wt} \%$ moisture and requires thermal drying. To thermally dry one tonne of microalgal slurry $\left(20^{\circ} \mathrm{C}\right)$ to $9.1 \%$ moisture, $780 \mathrm{~kg}$ water needs to be evaporated at $100^{\circ} \mathrm{C}$. Water has a specific heat of $4.187 \mathrm{~kJ} / \mathrm{kg} \cdot \mathrm{K}$ and latent heat $\left(\right.$ at $100^{\circ} \mathrm{C}$ ) of $2256.9 \mathrm{~kJ} / \mathrm{kg}$ [19].

Energy required for water evaporation:

$=780 \times 4.187 \mathrm{x}(100-20)+780 \times 2256.9=2,022 \mathrm{MJ}$

Eqn. 2

To evaporate $780 \mathrm{~kg}$ water from 1 tonne algal slurry, it will require at least $2,021,650 \mathrm{~kJ}$, which is approximately $2,022 \mathrm{MJ}$ or $562 \mathrm{kWh}$. This energy consumption is about 18.6 days of electricity usage of an American household [20]. Because the whole slurry shall be heated by the thermal dryer, the energy input for heating up rest water and microalgae can be calculated via following equations:

Energy required for heating $20 \mathrm{~kg}$ water to $100^{\circ} \mathrm{C}$ :

$=20 \times 4.187 \mathrm{x}(100-20)=6,699.2 \mathrm{~kJ}=1.86 \mathrm{kWh}$

Eqn. 3

Energy required for heating $200 \mathrm{~kg}$ microalgae to $100^{\circ} \mathrm{C}$ :

$=200 \times 1.57 \mathrm{x}(100-20)=25,120 \mathrm{~kJ}=6.98 \mathrm{kWh}$

Eqn. 4

The total energy for thermal drying of $1,000 \mathrm{~kg}$ microalgal slurry shall be equal to the sum of equations 2 through 4.

The total energy for thermal drying of $1,000 \mathrm{~kg}$ microalgal slurry:

$=2,021,650.8 \mathrm{~kJ}+6,699.2 \mathrm{~kJ}+25,120 \mathrm{~kJ}=2,053 \mathrm{MJ}=570 \mathrm{kWh}$

Eqn. 5

However, the overall thermal efficiency of spray dryers is only $20-50 \%$ [21]. Hence, if a dryer with $50 \%$ efficiency was used for drying the microalgal slurry, the total energy input for the drying process is $4,107 \mathrm{MJ}$ or $1140 \mathrm{kWh}$. If the thermal efficiency can be improved to $75 \%$ [22], the energy requirement reduced to $2,737,960 \mathrm{~kJ}$ (2738 MJ) or 760 $\mathrm{kWh}$. 


\section{Energy required for fast pyrolysis of microalgae}

It's reported that the energy required to achieve thermal conversion (i.e. pyrolysis) of six different microalgae at $500^{\circ} \mathrm{C}$ was found to be approximately $1 \mathrm{MJ} / \mathrm{kg}$ [13]. Because only dry microalgal samples were used in their study, the energy required to evaporate moisture must be considered too.

Energy required for evaporation of $20 \mathrm{~kg}$ water:

$=20 \times 4.187 \times(100-20)+20 \times 2256.9=51,837 \mathrm{~kJ}=23.6 \mathrm{kWh}$

Eqn. 6

Energy required for pyrolyzing $200 \mathrm{~kg}$ microalgae:

$=200 \times 1 \mathrm{MJ} / \mathrm{kg}=200 \mathrm{MJ}=200,000 \mathrm{~kJ}=55.6 \mathrm{kWh}$

Eqn. 7

Total energy required for pyrolysis of $220 \mathrm{~kg}$ microalgae

$=51,837 \mathrm{~kJ}+200,000 \mathrm{~kJ}=251,837 \mathrm{~kJ}=252 \mathrm{MJ}=70 \mathrm{kWh}$

Eqn. 8

If a pyrolyzer with $50 \%$ energy efficiency was used, the total energy input for the pyrolysis of microalgae rose to:

$=251,837 \mathrm{~kJ} \div 50 \%=503,674 \mathrm{~kJ}=504 \mathrm{MJ}=140 \mathrm{kWh}$

Eqn. 9

\section{Energy output from fast pyrolysis products}

Pyrolyzing $200 \mathrm{~kg}$ dry microalgae yielded $100 \mathrm{~kg}$ bio-oil, $30 \mathrm{~kg}$ water, $8 \mathrm{~kg}$ gases, and $56 \mathrm{~kg}$ biochar. The microalgal bio-oil was assumed to have a higher heating value of $30 \mathrm{MJ} / \mathrm{kg}$, so the energy output from the bio-oil is 3,000 MJ $(3,000,000 \mathrm{~kJ}=833 \mathrm{kWh})$. According to the composition of the gaseous products $\left(22.2 \mathrm{vol} \% \mathrm{H}_{2}, 34.9 \mathrm{vol} \% \mathrm{CH}_{4}, 38.6\right.$

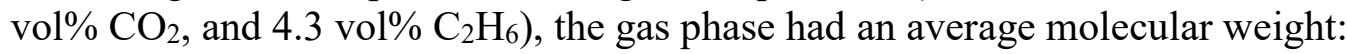

$\mathrm{MW}=2 \times 0.222+16 \times 0.349+44 \times 0.386+30 \times 0.043=24 \mathrm{~g} / \mathrm{mol}$ Eqn. 10

So, total gaseous products were $333.3 \mathrm{~mol}$ and $7,466.7 \mathrm{~L}\left(7.5 \mathrm{~m}^{3}\right)$ at normal temperature \& pressure conditions, including $1.665 \mathrm{~m}^{3} \mathrm{H}_{2}, 2.61 \mathrm{~m}^{3} \mathrm{CH}_{4}, 2.89 \mathrm{~m}^{3} \mathrm{CO}_{2}$, and $0.32 \mathrm{~m}^{3} \mathrm{C}_{2} \mathrm{H}_{6}$. The higher heating values of $\mathrm{H}_{2}, \mathrm{CH}_{4}$, and $\mathrm{C}_{2} \mathrm{H}_{6}$ are $12.769 \mathrm{MJ} / \mathrm{m}^{3}, 39.781$ $\mathrm{MJ} / \mathrm{m}^{3}$, and $69.693 \mathrm{MJ} / \mathrm{m}^{3}[23]$. The energy output from the gases:

$=12.769 \times 1.665+39.781 \times 2.61+69.693 \times 0.32=147.4 \mathrm{MJ}=41 \mathrm{kWh} \quad E q n$.

11

Because microalgal biochar is normally used as the soil amendment, total energy output from pyrolysis of $200 \mathrm{~kg}$ microalgae is $3,147.4 \mathrm{MJ}(3,147,400 \mathrm{~kJ}$ or $874 \mathrm{kWh})$.

\section{Energy required for microwave-assisted pyrolysis of microalgae}

Energy requirement for microwave-assisted pyrolysis was only experimentally determined for a benchtop system that converted 30-60 g dry microalgae. Based on their results, it required $317 \mathrm{~kJ}$ to pyrolyze $60 \mathrm{~g}$ microalgae to the bio-oil with a $404 \mathrm{~kJ}$ energy content and gases with a $283 \mathrm{~kJ}$ energy content [24]. The experiments in [24] were performed in a microwave oven, which normally is less than $60 \%$ efficient [25]. If scaling up this microwave oven linearly to a system processing $200 \mathrm{~kg}$ microalgae with the same efficiency, the microwave-assisted pyrolysis requires an energy input of 1,056,667 kJ (1,057 MJ or $293.5 \mathrm{kWh})$, producing the bio-oil of $52 \mathrm{~kg}$ with a 1346,666 kJ (1347 MJ or $374 \mathrm{kWh})$ energy content and gases of $44 \mathrm{~kg}$ with a 943,333 kJ (943 MJ or $262 \mathrm{kWh}$ ) energy content.

\section{Energy required for HTL of microalgae}

One tonne $(1,000 \mathrm{~kg})$ of microalgal slurry was processed via $\mathrm{HTL}$ at $350^{\circ} \mathrm{C}$. According to the steam table, the specific enthalpies of water (saturated liquid) at $20^{\circ} \mathrm{C}$ and 
$350^{\circ} \mathrm{C}(\sim 17 \mathrm{MPa} / 2,500 \mathrm{psia})$ are $83.9 \mathrm{~kJ} / \mathrm{kg}$ and $1,690 \mathrm{~kJ} / \mathrm{kg}$, respectively [26]. Energy required for heating $800 \mathrm{~kg}$ water from $20^{\circ} \mathrm{C}$ to $350^{\circ} \mathrm{C}$ :

$=800 \times(1690-83.9)=1,284,880 \mathrm{~kJ}=1,285 \mathrm{MJ}=357 \mathrm{kWh}$

Eqn. 12

Energy required for heating $200 \mathrm{~kg}$ microalgae from $20^{\circ} \mathrm{C}$ to $350^{\circ} \mathrm{C}$ :

$=200 \times 1.57 \times(350-20)=103,620 \mathrm{~kJ}=104 \mathrm{MJ}=29 \mathrm{kWh}$

Eqn. 13

The total energy required for heating this $1,000 \mathrm{~kg}$ microalgal slurry to $350^{\circ} \mathrm{C}$ is $1,389 \mathrm{MJ}$ or $386 \mathrm{kWh}$. If an electric heater with a $50 \%$ efficiency was used for this duty, the total energy required for HTL of microalgae is $2,778 \mathrm{MJ}(772 \mathrm{kWh})$. If a $75 \%$ thermal efficiency can be applied, the total energy required for HTL is $1,851 \mathrm{MJ}$ or $514 \mathrm{kWh}$.

Energy output from HTL products

Since the yield of bio-crude oil was $51 \%$, and thus the process yielded $102 \mathrm{~kg}$ biocrude with a $35 \mathrm{MJ} / \mathrm{kg}$ heating value [27]. Total energy recovered in the bio-crude oil was $3,570 \mathrm{MJ}$.

The gaseous products (42 vol\% $\mathrm{CO}_{2}, 50 \mathrm{vol} \% \mathrm{NH}_{3}, 7 \mathrm{vol} \% \mathrm{CH}_{4}$, and $1 \mathrm{vol} \%$ ethane) had an average molecular weight:

$\mathrm{MW}=44 \times 0.42+17 \times 0.5+16 \times 0.07+30 \times 0.01=28.1 \mathrm{~g} / \mathrm{mol}$

Eqn. 14

So, total gaseous products were $285 \mathrm{~mol}$ and $6,377 \mathrm{~L}\left(6.4 \mathrm{~m}^{3}\right)$ at normal temperature \& pressure conditions, including $2.7 \mathrm{~m}^{3} \mathrm{CO}_{2}, 3.2 \mathrm{~m}^{3} \mathrm{NH}_{3}, 0.45 \mathrm{~m}^{3} \mathrm{CH}_{4}$, and $0.06 \mathrm{~m}^{3} \mathrm{C}_{2} \mathrm{H}_{6}$. The higher heating values of $\mathrm{CH}_{4}$, and $\mathrm{C}_{2} \mathrm{H}_{6}$ are $39.781 \mathrm{MJ} / \mathrm{m}^{3}$ and $69.693 \mathrm{MJ} / \mathrm{m}^{3}$. The energy output from the combustible gases:

$=39.781 \times 0.45+69.693 \times 0.06=22 \mathrm{MJ}=6 \mathrm{kWh}$

Eqn. 15

\section{Results and Discussion}

To compare the energy consumption of different conversion technologies for microalgae, a 1,000 kg microalgal slurry was used as the baseline, and assumed to be processed with fast pyrolysis, microwave-assisted pyrolysis, and hydrothermal liquefaction processes. The energy requirements for the drying process and conversion reactors are summarized in Table 3 . The energy present in original microalgae, the bio-oil or bio-crude, and gases is also summarized in Table 3.

Table 3. Breakdown of energy consumption during pyrolysis and liquefaction of microalgae $\left(1,000 \mathrm{~kg}\right.$ slurry with $20 \%$ solids at $\left.20^{\circ} \mathrm{C}\right)$

\begin{tabular}{|l|l|l|l|}
\hline Energy (MJ) & $\begin{array}{l}\text { Fast Pyrolysis } \\
\left(500^{\circ} \mathrm{C}\right)\end{array}$ & $\begin{array}{l}\text { Microwave-assisted } \\
\text { Pyrolysis }\end{array}$ & HTL $\left(350^{\circ} \mathrm{C}\right)$ \\
\hline $\begin{array}{l}\text { Energy in microalgae }(20 \\
\text { MJ/kg) }\end{array}$ & 4,000 & 4,000 & 4,000 \\
\hline Drying & $4,107^{\mathrm{a}}$ & $4,107^{\mathrm{a}}$ & $\mathrm{N} / \mathrm{A}$ \\
\hline $\begin{array}{l}\text { Supporting conversion } \\
\text { reaction }\end{array}$ & $504^{\mathrm{a}}$ & $1,057^{\mathrm{b}}$ & $2,778^{\mathrm{a}}$ \\
\hline Total energy input & 4611 & 5,164 & 2,778 \\
\hline Bio-oil & 3000 & 1347 & 3570 \\
\hline Gas & 147 & 943 & 22 \\
\hline Total energy in products & 3147 & 2290 & 3592 \\
\hline Energy recovery & $78.7 \%$ & $57.2 \%$ & $89.8 \%$ \\
\hline
\end{tabular}

a: $50 \%$ efficiency

b: $25 \%$ efficiency 
The original $1,000 \mathrm{~kg}$ microalgal slurry with $200 \mathrm{~kg}$ dry microalgal cells carried $4,000 \mathrm{MJ}$ energy. If drying this slurry to a moisture content of $9.1 \%$ by using a spray dryer with a $75 \%$ efficiency, the energy requirement for the dryer was 2,738 MJ. One advantage of spray drying for microalgae is to directly generate find powders for the need of pyrolysis. However, the spray dryers generally have $20-50 \%$ efficiency, resulting in increased energy inputs of 4,107-10,267 MJ. Obviously, the efficiency of the drying system plays a very important role. If a drying system powered by renewable energies could be introduced into this process, the pyrolysis of microalgae will be more attractive.

The energy requirements for microalgae conversion were various for different techniques. Fast pyrolysis required the lowest amount of heat, because the process was considered to be conducted under the optimal conditions. Microwave-assisted pyrolysis was scaled up from a bench-top system with a low energy efficiency, and showed an energy requirement of $\sim 1,000 \mathrm{MJ}$ for converting $200 \mathrm{~kg}$ dry microalgae. Because pyrolyzing 200 $\mathrm{kg}$ microalgae requires an energy input of $252 \mathrm{MJ}$, the actual efficiency of this microwave pyrolysis system was approximately $25 \%$. Meanwhile, hydrothermally liquefying $1,000 \mathrm{~kg}$ microalgal slurry needed $\sim 2,778 \mathrm{MJ}$ (50\% efficient). The energy need for HTL was less than that of drying wet microalgae, because the evaporation process was avoided and HTL reactions happened in saturated water.

The product yields of fast pyrolysis and HTL were optimal numbers, which were projected from recent experimental studies and shall be realized in the near future. Both optimized pyrolysis and HTL processes should produce $\sim 50 \mathrm{wt} \%$ bio-oil or bio-crude oil with a higher heating value of $30-30 \mathrm{MJ} / \mathrm{kg}$, which is the main energy carrier for both processes. The combustible gas yields from both processes were relatively low and less than $4 \mathrm{wt} \%$. The energy recovery ratios from microalgae were $78.7 \%$ and $89.8 \%$ for fast pyrolysis and HTL, respectively. Because microalgae have a high ash content, resulting in a significant amount of ash and metals in the microalgal biochars. Normally, the microalgal biochars are considered as a good soil amendment.

The microwave-assisted pyrolysis process used for this study was not optimized, and produced large quantities of gases and less bio-oil products than fast pyrolysis or HTL. The energy recovery ratio for microwave-assisted pyrolysis was only $57.2 \%$. Microalgae are a poor microwave absorber too, so other materials like char and activated carbon are often added to help microwave absorption [28].

From the energy balance point of view, hydrothermal liquefaction is superior, and it could achieve the higher energy-recovery ratio with a lower energy cost.

Meanwhile, the pyrolysis of microalgae might still have its chance. The major advantage of microwave-assisted pyrolysis is that it can process feedstock with a large particles size even chunks, because of the unique heating approach. If the efficiency of microwave-assisted pyrolysis can be improved to that of fast pyrolysis, and solar drying can be applied to solve the negative energy issue (as shown in Figure 2), the pyrolysis of microalgae will be more promising. 


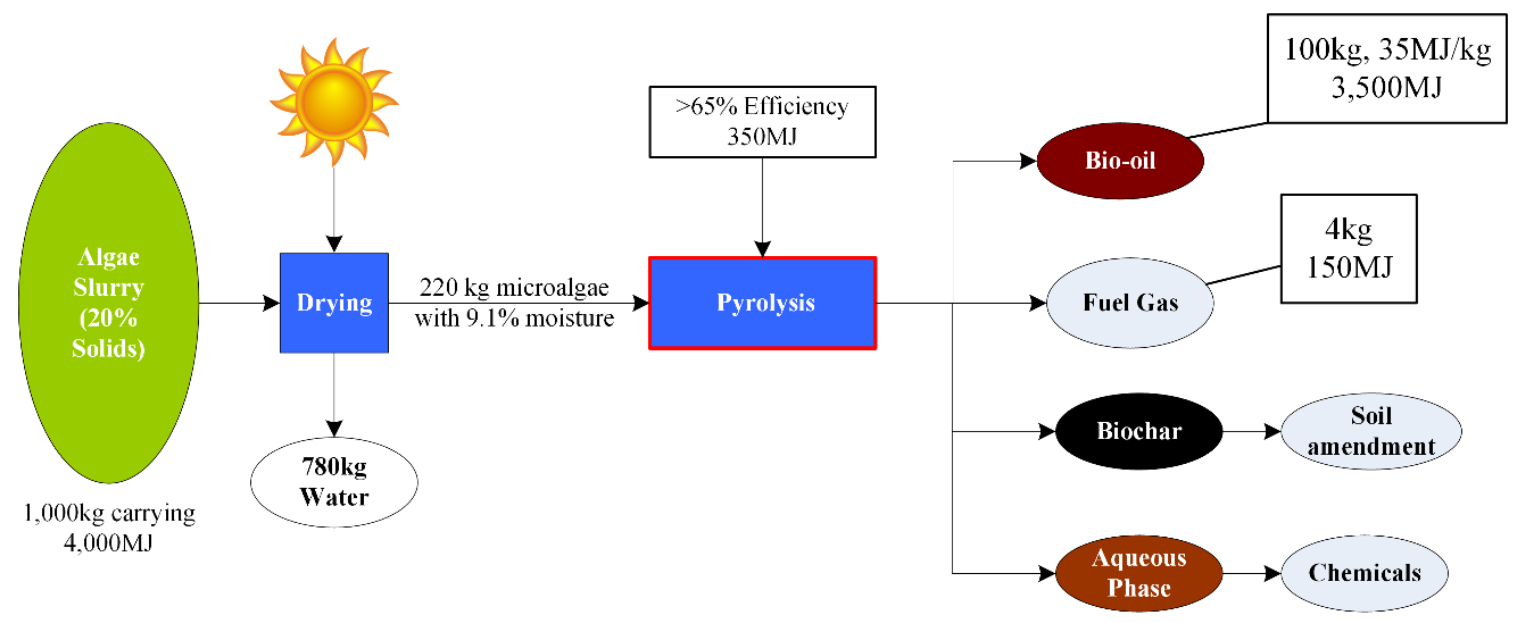

Figure 2. Proposed ideal pyrolysis process for microalgae

\section{CONCLUSIONS}

The energy requirements for converting one tonne $(1,000 \mathrm{~kg})$ of Chlorella slurry of $20 \mathrm{wt} \%$ solids via fast pyrolysis, microwave-assisted pyrolysis (MAP), and hydrothermal liquefaction (HTL) were compared. Drying microalgae prior to pyrolysis by using a spray drying process with $20 \%, 50 \%$, and $75 \%$ energy efficiency required energy inputs of 10,267 MJ, 4,107 MJ, and 2,738 MJ, respectively. The energy inputs to conduct fast pyrolysis, MAP, and HTL reactions were $504 \mathrm{MJ}$ (50\% efficient), 1,057 MJ ( 25\% efficient), and 2,776 MJ (50\% efficient), respectively. The microalgal feed contained 4,000 $\mathrm{MJ}$, and the energy recovery ratios for fast pyrolysis, MAP, and HTL of microalgae were $78.7 \%, 57.2 \%$, and $89.8 \%$, respectively. From the energy balance point of view, hydrothermal liquefaction is superior, and it achieved a higher energy recovery with a less energy cost. To improve the pyrolysis process, developing drying devices powered by renewable energies, optimizing the pyrolysis process, and improving the energy efficiency of equipment are options.

\section{ACKNOWLEDGMENTS}

We are grateful for the support from the School of Chemical Engineering and Pharmacy at the Wuhan Institute of Technology.

\section{CONFLICTS OF INTEREST}

The authors declare that there is no conflict of interests regarding the publication of this paper.

\section{REFERENCES}

[1] Yang, C., Li, R., Cui, C., Liu, S., Qiu, Q., Ding, Y., Wu, Y., and Zhang, B. (2016). Catalytic hydroprocessing of microalgae-derived biofuels: a review. Green Chemistry, 18(13), 3684-3699. DOI: 10.1039/c6gc01239f

[2] Chen, Y., Wu, Y., Hua, D., Li, C., Harold, M. P., Wang, J., and Yang, M. (2015). Thermochemical conversion of low-lipid microalgae for the production of liquid 
fuels: challenges and opportunities. RSC Advances, 5(24), 18673-18701. DOI: $10.1039 / \mathrm{c} 4 \mathrm{ra} 13359 \mathrm{e}$

[3] Elliott, D. C. (2016). Review of recent reports on process technology for thermochemical conversion of whole algae to liquid fuels. Algal Research, 13, 255-263. DOI: 10.1016/j.algal.2015.12.002

[4] Raheem, A., Wan Azlina, W. A. K. G., Taufiq Yap, Y. H., Danquah, M. K., and Harun, R. (2015). Thermochemical conversion of microalgal biomass for biofuel production. Renewable and Sustainable Energy Reviews, 49, 990-999. DOI: 10.1016/j.rser.2015.04.186

[5] Saber, M., Nakhshiniev, B., and Yoshikawa, K. (2016). A review of production and upgrading of algal bio-oil. Renewable and Sustainable Energy Reviews, 58, 918-930. DOI: 10.1016/j.rser.2015.12.342

[6] Yang, C., Li, R., Cui, C., Wu, J., Ding, Y., Wu, Y., and Zhang, B. (2017). The Pyrolysis of Duckweed over a Solid Base Catalyst: Py-GC/MS and TGA Analysis. Energy Sources, Part A: Recovery, Utilization, and Environmental Effects, 39 (2), 177-183. DOI: 10.1080/15567036.2016.1214641

[7] Jones, S. B., Zhu, Y., Anderson, D. M., Hallen, R. T., Elliott, D. C., Schmidt, A., Albrecht, K., Hart, T., Butcher, M., and Drennan, C. (2014). Process design and economics for the conversion of algal biomass to hydrocarbons: whole algae hydrothermal liquefaction and upgrading, Pacific Northwest National Laboratory.

[8] Jones, S. B., Zhu, Y., Snowden-Swan, L. J., Anderson, D., Hallen, R. T., Schmidt, A. J., Albrecht, K., and Elliott, D. C. (2014). Whole Algae Hydrothermal Liquefaction: 2014 State of Technology. Pacific Northwest National Laboratory (PNNL), Richland, WA (US).

[9] Du, Z., Li, Y., Wang, X., Wan, Y., Chen, Q., Wang, C., Lin, X., Liu, Y., Chen, P., and Ruan, R. (2011). Microwave-assisted pyrolysis of microalgae for biofuel production. Bioresource Technology, 102(7), 4890-4896. DOI: 10.1016/j.biortech.2011.01.055

[10] Borges, F. C., Xie, Q., Min, M., Muniz, L. A. R., Farenzena, M., Trierweiler, J. O., Chen, P., and Ruan, R. (2014). Fast microwave-assisted pyrolysis of microalgae using microwave absorbent and HZSM-5 catalyst. Bioresource Technology, 166, 518-526. DOI: 10.1016/j.biortech.2014.05.100

[11] Gong, X., Zhang, B., Zhang, Y., Huang, Y., and Xu, M. (2014). Investigation on Pyrolysis of Low Lipid Microalgae Chlorella vulgaris and Dunaliella salina.

Energy \& Fuels, 28(1), 95-103. DOI: 10.1021/ef401500z

[12] Thangalazhy-Gopakumar, S., Adhikari, S., Chattanathan, S. A., and Gupta, R. B. (2012). Catalytic pyrolysis of green algae for hydrocarbon production using H+ZSM-5 catalyst. Bioresource Technology, 118, 150-157. DOI:

10.1016/j.biortech.2012.05.080

[13] Grierson, S., Strezov, V., Ellem, G., McGregor, R., and Herbertson, J. (2009). Thermal characterisation of microalgae under slow pyrolysis conditions. Journal of Analytical and Applied Pyrolysis, 85(1-2), 118-123. DOI:

10.1016/j.jaap.2008.10.003

[14] Lin, L. (1985). Microstructure of spray-dried and freeze-dried microalgal powders. Food Structure, 4(2), 17.

[15] Zhang, B., Yang, C., Moen, J., Le, Z., Hennessy, K., Wan, Y., Liu, Y., Lei, H., Chen, P., and Ruan, R. (2010). Catalytic Conversion of Microwave-assisted 
Pyrolysis Vapors. Energy Sources, Part A: Recovery, Utilization, and Environmental Effects, 32(18), 1756-1762. DOI: 10.1080/15567030902842285

[16] Yang, C., Zhang, B., Moen, J., Hennessy, K., Liu, Y., Lin, X., Wan, Y., Lei, H., Chen, P., and Ruan, R. (2010). Fractionation and characterization of bio-oil from microwave-assisted pyrolysis of corn stover. Int J Agric \& Biol Eng, 3(3), 54-61. DOI: 10.3965/j.issn.1934-6344.2010.03.054-061

[17] Ruan, R., Chen, P., Hemmingsen, R., Morey, V., and Tiffany, D. (2008). Size matters: small distributed biomass energy production systems for economic viability. International Journal of Agricultural and Biological Engineering, 1(1), 64-68. DOI: 10.3965/j.issn.1934-6344.2008.01.064-068

[18] Elliott, D. C., Hart, T. R., Schmidt, A. J., Neuenschwander, G. G., Rotness, L. J., Olarte, M. V., Zacher, A. H., Albrecht, K. O., Hallen, R. T., and Holladay, J. E. (2013). Process development for hydrothermal liquefaction of algae feedstocks in a continuous-flow reactor. Algal Research, 2(4), 445-454. DOI: 10.1016/j.algal.2013.08.005

[19] Doran, P. M. (2013). Bioprocess engineering principles, Academic Press.

[20] U.S. EIA (2016). How much electricity does an American home use? https:/www.eia.gov/tools/faqs/faq.cfm?id=97\&t=3. (Accessed on 12/26/2016)

[21] Earle, R. L. (2013). Unit operations in food processing, Elsevier.

[22] APV (2000). APV Dryer Handbook. http://userpages.umbc.edu/ dfrey1/ench445/apv_dryer.pdf. (Accessed on $12 / 26 / 2016)$

[23] Waldheim, L., and Nilsson, T. (2001). Heating value of gases from biomass gasification. Report prepared for: IEA bioenergy agreement, Task, 20.

[24] Zhang, R., Li, L., Tong, D., and Hu, C. (2016). Microwave-enhanced pyrolysis of natural algae from water blooms. Bioresource Technology, 212, 311-317. DOI: 10.1016/j.biortech.2016.04.053

[25] Holladay, M. (2014). All About Microwave Ovens. http://www.greenbuildingadvisor.com/blogs/dept/musings/all-about-microwaveovens. (Accessed on 12/26/2016)

[26] Perry, R. H., and Green, D. W. (1999). Perry's chemical engineers' handbook, McGraw-Hill Professional.

[27] Biller, P., Sharma, B. K., Kunwar, B., and Ross, A. B. (2015). Hydroprocessing of bio-crude from continuous hydrothermal liquefaction of microalgae. Fuel, 159, 197-205. DOI: 10.1016/j.fuel.2015.06.077

[28] Xie, Q., Addy, M., Liu, S., Zhang, B., Cheng, Y., Wan, Y., Li, Y., Liu, Y., Lin, X., Chen, P., and Ruan, R. (2015). Fast microwave-assisted catalytic co-pyrolysis of microalgae and scum for bio-oil production. Fuel, 160, 577-582. DOI:

10.1016/j.fuel.2015.08.020

Article Copyright: (C) 2017 Bo Zhang, Jinsheng Wu, Zhao Deng, Changyan Yang, Chang Cui, and Yigang Ding. This is an open access article distributed under the terms of the Creative Commons Attribution 4.0 International License, which permits unrestricted use and distribution provided the original author and source are credited.

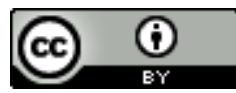

